\title{
触 New Disease Reports \\ First report of Chilli leaf curl India virus infecting Mirabilis jalapa in India
}

M. Jaidi, S. Kumar and S.K. Raj*

Plant Molecular Virology Laboratory, CSIR-National Botanical Research Institute, Lucknow-226001, India

*E-mail: skraj2@rediffmail.com

Received: 14 Oct 2016. Published: 06 Jan 2017.

Mirabilis jalapa (family Nyctaginaceae), also known as the four-o'clock plant, is an ornamental flowering plant grown widely in gardens for the beauty of its variously coloured flowers. Possible disease symptoms (Fig. 1) were observed on a number of $M$. jalapa plants growing in the gardens of CSIR-NBRI, Lucknow ( $26^{\circ} 55^{\prime} \mathrm{N}$; $\left.80^{\circ} 59^{\prime} \mathrm{E}\right)$, India. The disease incidence was about $45 \%$ with plants exhibiting upward leaf curling and stunting in comparison with apparently healthy plants (Fig. 2). Based on the symptoms a begomovirus infection was suspected.

Total DNA was isolated from the leaves of 17 diseased and one asymptomatic $M$. jalapa plants and subjected to PCR using begomovirus degenerate primers (Rojas et al., 1993). An amplicon of the expected size (c. $1.2 \mathrm{~kb}$ ) was produced from all 17 diseased samples, confirming begomovirus infection. The full length virus genome (c. $2.7 \mathrm{~kb}$ ) was amplified using the rolling-circle amplification method, cloned and sequenced (GenBank Accession No. KX951415). The sequence showed 92-99\% nucleotide sequence identity and a close phylogenetic relationship (Fig. 3) with isolates of Chilli leaf curl India virus (ChiLCINV) identified in Duranta repens (KT948070) from Pakistan, and in Capsicum sp. (FM877858), and Mentha arvensis (KT779820) and spicata (KF312364) from India. This shows the virus detected in M. jalapa to be an isolate of ChiLCINV.

M. jalapa has been reported to be infected by Parietaria mottle virus (genus Ilarvirus) in Italy, Mirabilis jalapa mottle virus (genus Carlavirus) in the USA, Basella rugose mosaic virus (genus Potyvirus) in China (Parrella, 2002; Hatlestad et al., 2011; Wang et al., 2012), and Mirabilis mosaic virus (genus Caulimovirus) in the USA (Brunt \& Kitajima, 1973). Recently, Tomato chlorotic spot virus (genus Tospovirus) has also been reported to infect M. jalapa in Brazil (Duarte et al., 2016). ChiLCINV has been isolated from Capsicum sp., M. arvensis and spicata in India and D. repens in Pakistan. This is the first report of ChiLCINV infecting M. jalapa.

\section{References}

Brunt AA, Kitajima EW, 1973. Intracellular location and some properties of Mirabilis mosaic virus, a new member of the cauliflower mosaic group of viruses. Journal of Phytopathology 76, 265-275. http://dx.doi.org/10.1111/j.1439-0434.1973.tb02669.x

Duarte LML, Chaves ALR, Kitajima EW, Rodrigues LK, Harakava R, Alexandre MAV, 2016. First report of Tomato chlorotic spot virus on Mirabilis jalapa. Australasian Plant Disease Notes 11, 6. http://dx.doi.org/10.1007/s13314-016-0193-6

Hatlestad GJ, Elam L, Gonzalez A, Lloyd AM, 2011. Mirabilis jalapa mottle virus: a new carlavirus infecting four o'clocks. Archives of Virology 156, 2109-2111. http://dx.doi.org/10.1007/s00705-011-1101-1

Parrella G, 2002. First report of Parietaria mottle virus in Mirabilis jalapa. Plant Pathology 51, 401 http://dx.doi.org/10.1046/j.1365-3059.2002.00717.x

Wang JG, Peng JJ, Chen HR, Chen SY, 2012. First report of Basella rugose mosaic virus infecting four o'clock (Mirabilis jalapa) in China. Plant Disease 96, 294. http://dx.doi.org/10.1094/PDIS-07-11-0586

Rojas MR, Gilbertson RL, Russell DR, Maxwell DP, 1993. Use of degenerate primers in the polymerase chain reaction to detect whiteflytransmitted geminiviruses. Plant Disease 77, 340-347.

http://dx.doi.org/10.1094/PD-77-0340
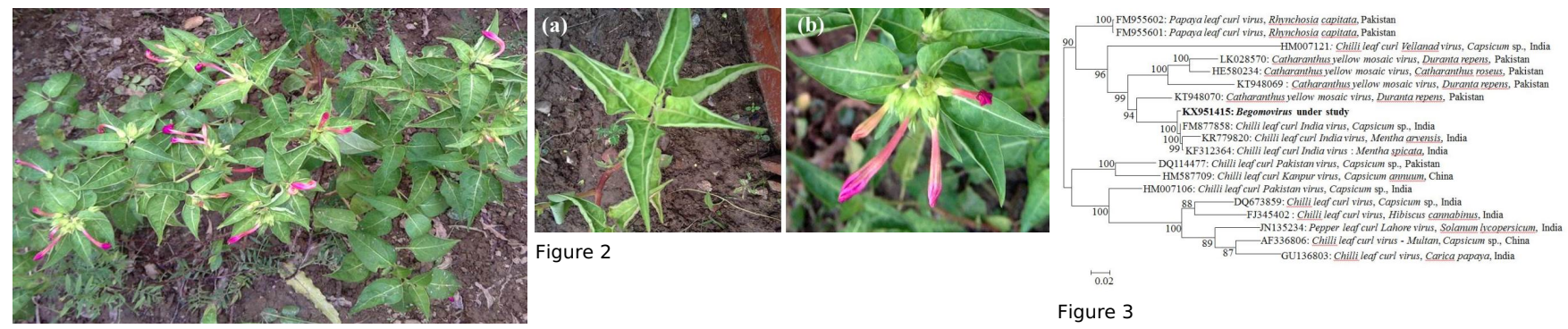

Figure 2

Figure 1

Figure 3

To cite this report: Jaidi M, Kumar S, Raj SK, 2017. First report of Chilli leaf curl India virus infecting Mirabilis jalapa in India. New Disease Reports 35, 2. http://dx.doi.org/10.5197/j.2044-0588.2017.035.002 